\title{
単一成分および多成分有機溶液中における軟鋼の腐食挙動*
}

\author{
関根 功**,***, 湯 浅 真 ${ }^{* *}, * * *$, 可児一郎** \\ ** 東京理科大学理工学部工業化学科 \\ *** 東京理科大学界面科学研究所
}

\section{Corrosion Behavior of Mild Steel in Organic Solutions of One Component and Multicomponent Systems*}

\author{
Isao Sekine**,***, Makoto Yuasa ${ }^{* *, * * *}$ and Ichiro Kani ${ }^{* *}$ \\ ** Department of Industrial Chemistry, Faculty of Science and Technology, \\ Science University of Tokyo \\ *** Institute of Colloid and Interface Science, Science University of Tokyo
}

\begin{abstract}
The corrosion behavior of SS 400 (mild steel) was investigated in one component system of pure organic solvents (acetic acid, ethanol, diethylamine and acetone) and multicomponent system of organic solutions containing additive agents (water, lithium perchlorate, sulfuric acid and nitric acid) by the corrosion weight loss tests, electrochemical measurements and surface analyses. From these results, the corrosion of mild steel was remarkably promoted by sulfuric acid and nitric acid in organic solutions. The corrosion rate increased in strong basic solvent (ethanol), and decreased in weak basic solvent (acetic acid) by addition of sulfuric acid. The passive state region was observed in wide potential range on anodic polarization curves, and the rest potential existed in passive state region in non-corrosion systems. In a.c. impedance measurements, the charge transfer process was observed in remarkable corrosion systems, and the film resistance of passive state was increased in non-corrosion systems. In surface analysis by XPS, the salt film of acetate on steel surface was observed in acetic acid of corrosion system, while the passive film made up by adsorption of solvent molecules and the oxides was observed in ethanol or acetone of non-corrosion systems.
\end{abstract}

Key words : corrosion, mild steel, organic solution, one component, multicomponent

\section{1. 緒言}

化学製造プロセスの装置で, 有機溶媒中の金属の腐食 が問題となっており，様々な事例が報告されてきた ${ }^{1) 。}$ 有機溶媒の物性は水と大きく異なるため耐食性に大きな 影響を与える。従って有機溶媒中での腐食は水溶液中に 比べて予想できないほどに特徴的な挙動を示すものが多 い。有機溶媒の種類は極めて多く, 金属/有機溶媒系の 種類も膨大な数に達する。

$\mathrm{Heitz}^{2)}$ は，有機溶媒の分類之金属の腐食挙動の検討 を行った。分類にあたって, 純溶媒がプロトン性か非プ

* 腐食防食'94（つくば, 1994 年）で一部発表

** 三278 野田市山崎 2641（2641, Yamazaki, Noda, 278 Japan)

*** 7162 東京都新宿区神楽坂 1-3（3, Kagurazaka 1-chome, Shinjuku-ku, Tokyo, 162 Japan)
ロトン性のいずれか，またその溶媒の成分数および相数 （一相か多相か）がどのようになっているかが重要であ る。有機溶媒系では一般に, 腐食反応が進行するとき, 攻撃性のある試薬と腐食生成物が, 溶解して溶媒和され る必要がある。有機溶媒は多くの場合化学的に純粋でな く，製造プロセスや以前に行った反応によって水，酸， 金属化合物などの不純物を含み，これらの物質の影響を 強く受けることが知られている。

有機溶媒中での金属の腐食挙動は 1970 年代まで数 例3) 7)に過ぎなかったが, Heitz (1974 年) ${ }^{2)}$ が総説の 中で各種有機溶媒中の金属の腐食について一部を分類し 体系化して以来, 組織的な研究が行われるようになって きた。Heitz と Czepurnyi ${ }^{8)}$ は, 腐食速度と不純物濃 度に関する研究を行い，不純物が加速因子あるいは抑制 因子として作用する結果を得た。Kerry と Moran ${ }^{9)}$ は 
非水有機溶液中で不動態化が起こる機構を総説し, 金属 表面上の保護性皮膜形成における酸と水の影響を論じ, 酸性・中性溶液中の金属の不動態挙動における影響を実 験し説明した。Farina と Olivani ら ${ }^{10}$ )はメタノール溶 液中の純鉄の不動態形成と安定性を, 含水量と $\mathrm{Cl}^{-}$イオ

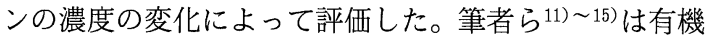
酸, アルコール, DMF, DMSO 中での軟鋼, ステン レス鋼の腐食挙動についての組織的研究を展開し, 一連 の報告を行っている。

本報では，有機溶媒をプロトン性 [酸性溶媒，両性溶 媒, 塩基性溶媒] および, 非プロトン性に分類し，それ ぞれの溶媒を代表する各純溶媒の一成分系と微量不純物 の影響を調べるために, 添加物を含む多成分系有機溶液 中の鋼材の腐食挙動と保護皮膜について検討した。測定 は，それぞれ室温系と沸点系について，腐食挙動として 腐食重量減試験, 電気化学的挙動として分極曲線の測 定, 自然電位の経時変化の測定, 交流インピーダンスの 測定,さらに表面解析としてXPS による評価を行った。

\section{2. 実験方法}

\section{1 試験片および試験溶液}

腐食重量減試験には, 試験片として $20 \times 20 \times 1.55$ $\mathrm{mm}$ のSS 400 鋼板 ( $\mathrm{C}: 0.04, \mathrm{Si}:$ trace, $\mathrm{Mn}: 0.30$, $\mathrm{P}: 0.020, \mathrm{~S}: 0.017 \%, \mathrm{Fe}$ :bal.) を使用し, 電気化 学的測定には鋼材を $3.65 \mathrm{~mm}^{2}$ の断面のみ残して他の面 を熱収縮ポリテトラフルオロエチレン (PTFE) チュー ブでシールドした SS 400 鋼を電極として使用し，表面 解析には高純度電解鉄（99.995\%）を使用した。

使用した試験溶液の各種有機溶媒として, (1)酥酸（酸 性溶媒)，(2)エ夕ノール (両性溶媒), (3)ジエチルアミ ン（塩基性溶媒）および (4) アセトン（非プロトン性） の単一成分系とこれらに添加物として硫酸, 硝酸, 過塩 素酸リチウムおよび水を加えた多成分系の有機溶液を調 製した。

溶媒の脱水法として，酢酸は試薬特級（99.5\%）1 $\mathrm{dm}^{3}$ につき五酸化二リン $10 \mathrm{~g}$ を添加し 48 時間以上放 置してから, 常圧蒸留した。エタノールは試薬特級 （99.5\%） $1 \mathrm{dm}^{3}$ につき金属ナトリウム $7 \mathrm{~g}$ を添加し， 完全に反応した後, フタル酸ジエチルを $24.5 \mathrm{~cm}^{3}$ 添加 して 3 時間還流後常圧蒸留した。ジエチルアミンとアセ トンは試薬特級 $1 \mathrm{dm}^{3}$ につきモレキュラーシーブ $20 \mathrm{~g}$ 添加し，5 日間放置してからろ過した。

各種測定を行う前に溶液の脱気を行った。脱気法とし て, 沸点系では 2 時間還流し, 溶存する空気を追い出 し, 室温系では溶液 $1 \mathrm{dm}^{3}$ につき 2 時間乾燥窒素で窒 素置換し酸素の影響を取り除いた。

\section{2 腐食重量減試験}

腐食重量減試験は，SS 400 鋼板（ $20 \times 20 \times 1.55 ） を$ エメリ一紙で $240 ， 400 ， 800 ， 1200 ， 1500$ 番の順番で研 磨し, メタノールに 3 分間浸漬して脱水, アセトンで 30 秒間超音波洗浄を行った。浸漬期間は沸点系で 1 日間 $\left(1.0 \mathrm{~N}\right.$ 硝酸添加酢酸系 : 6 時間), 室温系 $\left(25^{\circ} \mathrm{C}\right)$ で 3 日間とし, 溶液量は $200 \mathrm{~cm}^{3}$ とした。後処理は沸騰 $\mathrm{Zn}$ 粉末添加 $20 \mathrm{wt} \% \mathrm{KOH}$ 溶液中に試験片を 12 分間放置 し，その後メタノールで脱水してからアセトンで超音波 脱脂し, 乾燥後重量測定した。溶液の添加物濃度は, $0.02 ， 0.1 ， 0.5$ および $1.0 \mathrm{~N}$ とし濃度変化の影響を検 討した。

\section{3 電気化学的測定}

電気化学的測定は, 分極曲線の測定, 自然電極電位の 経時変化の測定, 交流インピーダンス測定を行った。

溶媒一成分系では支持電解質として, 沸点酶酸系用に 酶酸カリウムと他の系用に過塩素酸リチウムを，それぞ れ 5 時間以上加熱, 真空乾燥して用いた。硫酸, 硝酸, 過塩素酸リチウム添加系では添加物をそのまま支持電解 質として使用した。また水添加系では支持電解質とし て, 沸点酷酸系では酶酸カリウム, 他の系では過塩素酸 リチウムを添加した。支持電解質の濃度はすべて $0.5 \mathrm{~N}$ とした。

調製した溶液は，モレキュラーシーブを添加後 7 日間 放置して脱水後使用した。

\section{3.1 分極曲線の測定}

温度は各溶液につき室温 $25^{\circ} \mathrm{C}$ と沸点で測定し, 溶液 量は $300 \mathrm{~cm}^{3}$ とした。作用極は側面をPTFE で被覆し た SS 400 鋼板 $\left(4 \mathrm{~mm}^{2}\right)$ を用い，対極は白金線をラセ ン状にしたものを使用した。参照極は銀-銀イオン $\left(\mathrm{Ag} / \mathrm{Ag}^{+}\right)$電極とし, 有機溶媒に硝酸銀を $0.01 \mathrm{M}$ 溶 解させて用いた。測定はポテンシオスタット（北斗電工 HA-301), アンメーター (北斗電工 HM-104), ファン クションジェネレイター（北斗電工 HB-104）の機器を 用い, 試験極を- $1.5 \mathrm{~V}$ vs. $\mathrm{Ag} / \mathrm{Ag}^{+}$で 10 分間定電位 還元後, 直ちに自然電位 $\left(E_{\mathrm{corr}}\right)$ から走查速度 $50 \mathrm{mV} /$ min の動電位法でカソード側に $-0.3 \mathrm{~V}$ 分極し,この 電位からアノード側の $+1.5 \mathrm{~V}$ まで分極させて行った。

\section{3.2 自然電極電位の経時変化の測定}

試験溶液, 鋼材, 測定装置, セル，条件は分極曲線の 測定と同様にして行い, 試験極を-1.5 V vs. $\mathrm{Ag} / \mathrm{Ag}^{+}$ で 10 分間定電位還元後，ポテンシャルレコーダー（東 亜電波工業 EPR-111 A）を用いて自然電位の経時変化 を 24 時間測定した。また参照極として $\mathrm{Ag} / \mathrm{Ag}^{+}$電極を 用いた。

\subsection{3 交流インピーダンス測定}

交流インピーダンス測定は, 自然電位の経時変化を 
(1) $\mathrm{CH}_{3} \mathrm{COOH}$

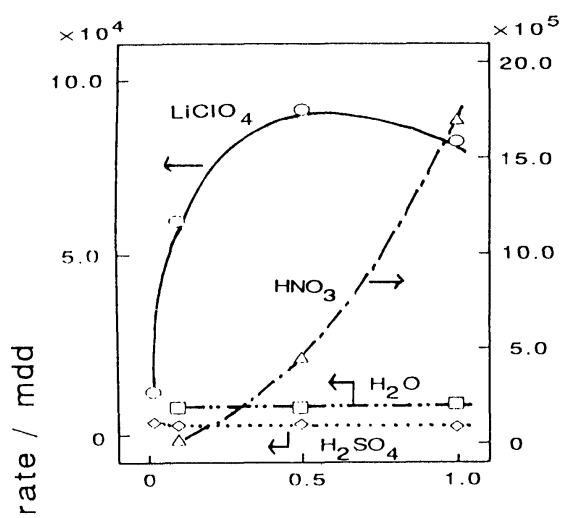

(3) $\left(\mathrm{C}_{2} \mathrm{H}_{5}\right){ }_{2} \mathrm{NH}$

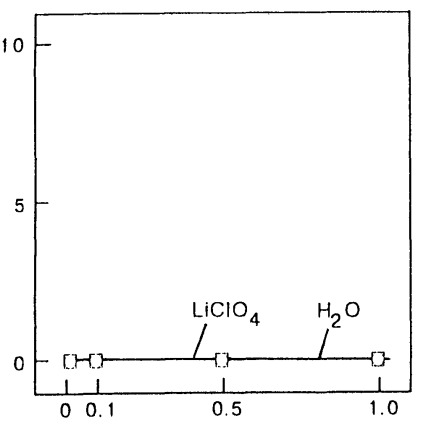

(2) $\mathrm{C}_{2} \mathrm{H}_{5} \mathrm{OH}$

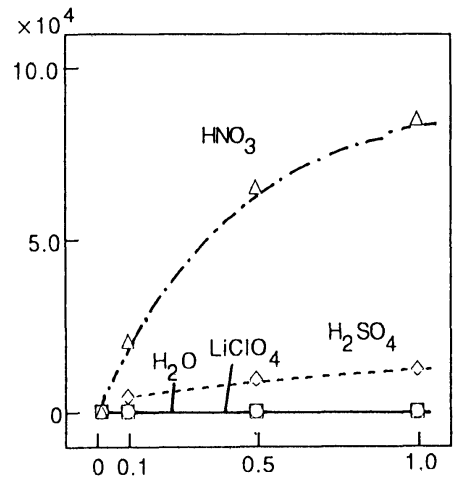

(4) $\mathrm{CH}_{3} \mathrm{COCH}_{3}$

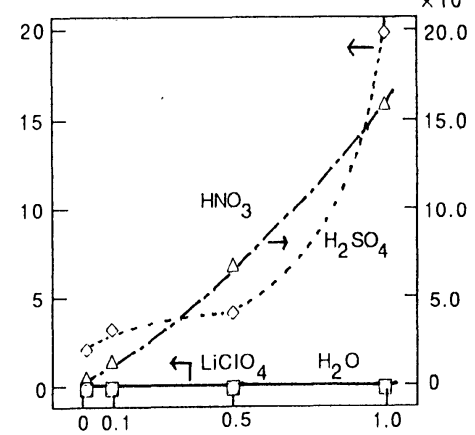

Concentration / N

Fig. 1 Corrosion rates of SS 400 in various solutions at b.p.

24 時間測定後電位が一定になったことを確認してから, ポテンシオスタット（東方技研 Model 2000）で自然電 位に設定し, 周波数特性分析器（NF 回路設計ブロック Model 5020）と連動させて $20 \mathrm{kHz}$ から $10 \mathrm{mHz}$ まで 測定した。試験溶液, 鋼材, 測定装置, セル, 条件は分 極曲線の測定と同様にして行った。

\subsection{XPS による表面分析}

脱気した室温下での酢酸, エタノール, アセトン中に 1 日間浸漬した試験片表面を $\mathrm{X}$ 線光電子分光装置（島 津製作所製 ESCA-850）を用いて分析した。このとき エッチングイオンとして $\mathrm{Ar}^{+}$を用い, エッチング速度 は約 $10 \mathrm{~nm} / \mathrm{min}$ であった。 $\mathrm{X}$ 線源には $\mathrm{Mg} \mathrm{K} \alpha$ を用い た。

\section{3. 結果および考察}

\section{1 酢 酸 系}

\subsection{1 腐食重量減試験}

沸点酢酸系（Fig. 1 (1)）では, 酢酸単一成分中での SS 400 鋼の腐食速度はかなり大きく, $5.0 \times 10^{3} \mathrm{mdd} \sim$
$1.0 \times 10^{4} \mathrm{mdd}$ となった。このときの腐食の形態は全面 腐食で, 試験片表面は灰白色となり腐食生成物は試験溶 液に完全に溶出し，溶液は赤褐色となった。

硫酸を添加した場合, 酢酸単一成分に比べて腐食速度 はわずかに減少した。これは, 硫酸が水溶液中の場合と 異なり，弱酸として作用したためである。水以外の溶媒 の場合, 溶媒の塩基性の強度が酸（HA）の強度を決定 する。酢酸は弱酸であるため下式のプロトン解離はわず かな範囲でしか起こらないと考えられる ${ }^{16)} 。$

$$
\mathrm{H}_{2} \mathrm{SO}_{4}+\mathrm{CH}_{3} \mathrm{COOH} \rightleftarrows \mathrm{CH}_{3} \mathrm{COOH}_{2}{ }^{+}+\mathrm{HSO}_{4}{ }^{-}
$$

このため腐食速度は酢酸一成分系より減少したと考えら れる。

硝酸を添加した場合, 腐食速度は著しく增加した。こ れは混合物中の硝酸の酸化力が極めて強く, 次の反応が 生じていると考えられる。

$$
\mathrm{Fe}+4 \mathrm{HNO}_{3} \rightarrow \mathrm{Fe}\left(\mathrm{NO}_{3}\right)_{3}+\mathrm{NO}+2 \mathrm{H}_{2} \mathrm{O}
$$

過塩素酸リチウムを添加した場合, 腐食速度はかなり 急増し， $0.5 \mathrm{~N}$ 以上の濃度ではほぼ一定になった。これ 
(1) $\mathrm{CH}_{3} \mathrm{COOH}$

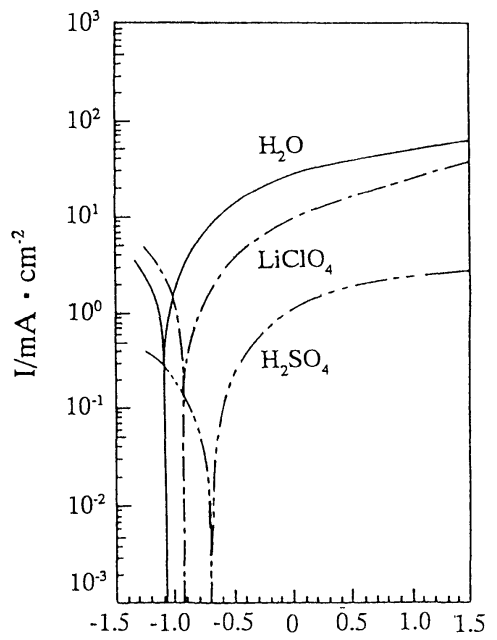

(2) $\mathrm{C}_{2} \mathrm{H}_{5} \mathrm{OH}$

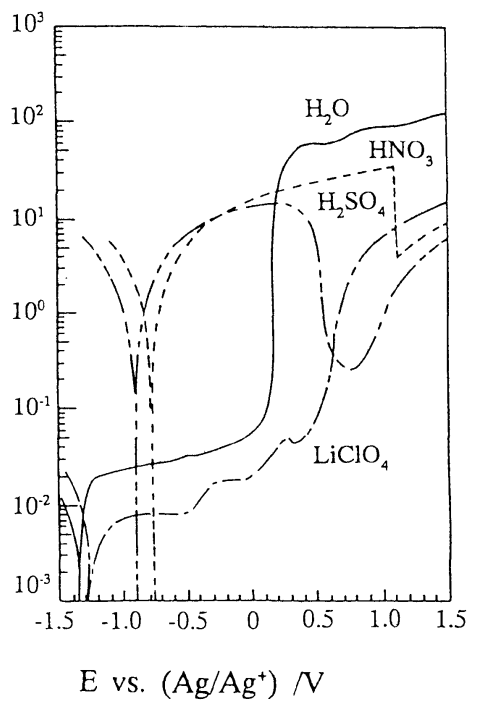

(3) $\mathrm{CH}_{3} \mathrm{COCH}_{3}$

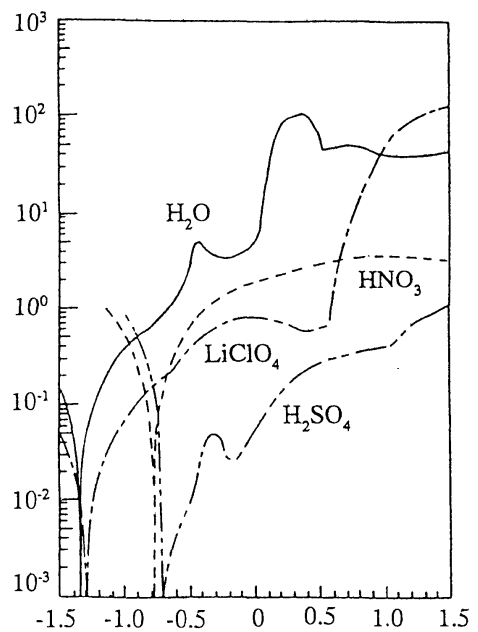

Fig. 2 Polarization curves of SS 400 in various solutions at b.p.

は下式17)のように溶液中の過塩素酸リチウムが高温のた め酸化剤として作用したと考えられる。

$$
\mathrm{ClO}_{4}^{-}+2 \mathrm{H}^{+}+2 \mathrm{e}^{-} \longrightarrow \mathrm{ClO}_{3}{ }^{-}+\mathrm{H}_{2} \mathrm{O}
$$

水を添加することによって腐食速度はやや増加した。 このことは $\mathrm{H}_{2} \mathrm{O}$ を加えることにより $\mathrm{CH}_{3} \mathrm{COOH}$ が解 離して生じた $\mathrm{H}_{3} \mathrm{O}^{+}$が鋼材を腐食したことによる。

$$
\mathrm{CH}_{3} \mathrm{COOH}+\mathrm{H}_{2} \mathrm{O} \rightleftarrows \mathrm{CH}_{3} \mathrm{COO}^{-}+\mathrm{H}_{3} \mathrm{O}^{+}
$$

室温酢酸系では, 酶酸一成分系の腐食速度は $5.5 \times 10$ mdd とかなり小さな值となった。これは温度が沸点系 に比べて低いため腐食が進行しなかったことによる。

硫酸, 硝酸, 水添加系の腐食速度は, 沸点系に比べて 小さな值を示したが, 沸点系と同じ傾向を示したので, 同様な腐食機構が起こったと考えられる。過塩素酸りチ ウム添加系では, 腐食速度はやや増加した。これは室温 $\left(25^{\circ} \mathrm{C}\right)$ では酸化剂として作用せず，非酸化性の塩とし て作用したと考えられる。

\section{1 .2 分極曲線測定}

沸点䣷酸系の分極曲線（Fig. 2 (1) で）アノード反 応では不動態, カソード反応では反応抑制の領域は見ら れず，いずれの系でも活性溶解が進行したことがわか る。しかし, 硫酸添加系ではアノードおよびカソード分 極曲線の電流密度が最も小さく, アノードおよびカソー ド反応が抑制されていた。このため腐食反応は他の系に 比べて進行しなかったと考えられる。

水添加系のカソード反応は, $\mathrm{H}_{2} \mathrm{O}$ が $\mathrm{CH}_{3} \mathrm{COOH}$ に よってプロトン供与された $\mathrm{H}_{3} \mathrm{O}^{+}$の還元反応である。

$$
2 \mathrm{H}_{3} \mathrm{O}^{+}+2 \mathrm{e}^{-} \longrightarrow 2 \mathrm{H}_{2} \mathrm{O}+\mathrm{H}_{2}
$$

硫酸添加系のカソード反応は，(6)式 ${ }^{18)}$ の反応で生成 した酥酸イオンが水素発生のプロトン供与物質として作 用する $\mathrm{CH}_{3} \mathrm{COOH}_{2}+$ の還元反応が考えられる。

$$
\mathrm{CH}_{3} \mathrm{COOH}_{2}{ }^{+}+2 \mathrm{e}^{-} \longrightarrow \mathrm{CH}_{3} \mathrm{COO}^{-}+\mathrm{H}_{2}
$$

硝酸添加系では，(7)式199 のように強い酸化力を持っ た硝酸の還元反応が生じ，このため著しい腐食速度の増 加が起きたと考えられる。硝酸添加系の分極曲線は電位 が安定しなかったため図に示すことができなかった。

$$
\mathrm{NO}_{3}{ }^{-}+4 \mathrm{H}^{+}+4 \mathrm{e}^{-} \longrightarrow \mathrm{NO}+2 \mathrm{H}_{2} \mathrm{O}
$$

室温酢酸系の分極曲線測定では, 水および過塩素酸リ チウム添加系でわずかなアノード反応抑制域が観察され た。これは酶酸鉄の塩皮膜が形成されたことによるが, 貴な電位に存在していたため腐食抑制に寄与することな く沸点系同様いずれの系でも活性溶解が進行した。

硫酸添加系ではアノード反応が沸点系に比べかなり抑 制され，このため腐食速度が各系の中で最小值（約 0.05 $\left.\mathrm{mA} / \mathrm{cm}^{2}\right)$ を示した。酸性溶液中では酸化物による不 動態形成は困難であり，不動態による腐食抑制は起こら ない。一方硝酸添加系ではアノード反応抑制域は観察さ れず腐食速度は大きな值を示した。

カソード反応は, 沸点系と同じ反応が起きているが, 過塩素酸リチウム添加系では沸点系と異なり, 取り除く ことのできなかった微量の水がプロトン供与され，(5) 式で示した $\mathrm{H}_{3} \mathrm{O}^{+}$の還元反応が想定される。

\subsection{3 自然電位経時変化測定}

沸点䣷酸系の自然電位の経時变化の測定 (Fig. 3 (1)) では, 還元後直ちに貴な電位に移行し安定した。24 時 
(1) $\mathrm{CH}_{3} \mathrm{COOH}$

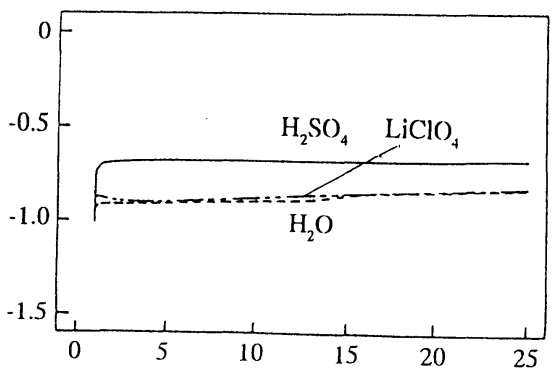

(2) $\mathrm{C}_{2} \mathrm{H}_{5} \mathrm{OH}$

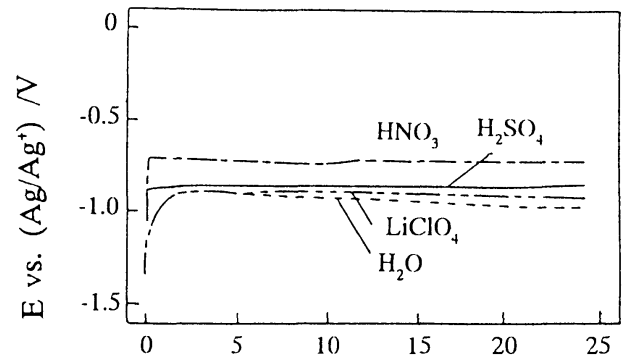

(3) $\mathrm{CH}_{3} \mathrm{COCH}_{3}$

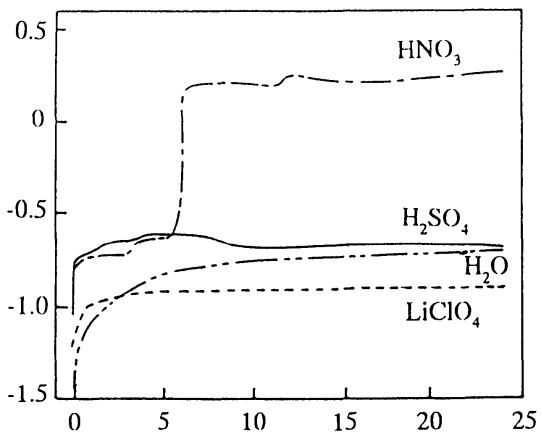

Time/h

Fig. 3 Rest potentials of SS 400 in various solutions at b. p.

間後の自然電位はいずれも活性化支配域に存在し，活性 溶解の進行が推測される。硫酸添加系の自然電位は $-0.66 \mathrm{~V}$ で, 過塩素酸リチウム添加系の $-0.86 \mathrm{~V}$ や水 添加系の $-0.85 \mathrm{~V}$ より貴な電位を示し, $\mathrm{CH}_{3} \mathrm{COOH}_{2}{ }^{+}$ $\mathrm{H}_{2}$ の酸化還元電位が $\mathrm{H}_{3} \mathrm{O}^{+} / \mathrm{H}_{2}$ の酸化還元電位より貴 な電位であると考えられる。硝酸添加系の自然電位は安 定しなかったため図に示すことはできなかった。

室温䣷酸系の自然電位の経時変化の測定では, 還元後 直ちに貴な電位に移行した。自然電位は沸点系と同じく 活性化支配領域に存在し, 活性溶解が進行したことが考 えられる。硝酸添加系では， $-0.85 \mathrm{~V}$ と卑な電位を示 した。

\subsection{4 交流インピーダンス測定}

沸点酶酸系の交流インピーダンス測定の Cole-Cole プロット（Fig. 4 (1)）では, 24 時間後の自然電位に設 定して測定したところ，完全な円弧が一つ得られ，活性 化支配される酸素を含まない酸性水溶液中の鉄腐食と同 じプロットを示した。電極表面は図中に示した二重層容 量 $C_{\mathrm{cl}}$ を持つコンデンサーと電荷移動抵抗 $R_{\mathrm{ct}}$ 之溶液抵 抗 $R_{\text {sol }}$ からなる等価回路が存在し，酸性水溶液中之同

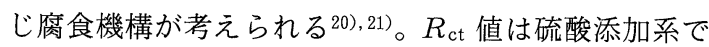
$9.3 \times 10 \Omega \mathrm{cm}^{2}$, 酢酸カリウム添加系（ブランク）で $5.3 \Omega \mathrm{cm}^{2}$ を示し, 抵抗が大きい系で腐食速度が小さく なることが判明した。沸点系では系が乱れるため, 過塩 素酸リチウムおよび水添加系では円弧の一部しか得られ なかった。 $R_{\mathrm{ct}}$ 之電流密度との間に次の関係がある。

$$
i=\frac{R \cdot(273+T)}{Z \cdot F \cdot R_{\mathrm{ct}}}
$$

インピーダンス測定より求めた硫酸添加系の電流密度 は $3.2 \times 10^{-3} \mathrm{~A} \cdot \mathrm{cm}^{-2}$, 酢酸カリウム添加系の電流密度 は $1.8 \times 10^{-4} \mathrm{~A} \cdot \mathrm{cm}^{-2}$ となり, 重量減試験の結果から求 めた電流密度（硫酸添加系 $2.8 \times 10^{-3} \mathrm{~A} \cdot \mathrm{cm}^{-2}$, 酢酸力 リウム添加系 $\left.3.0 \times 10^{-5} \mathrm{~A} \cdot \mathrm{cm}^{-2}\right)$ と一致する傾向を示 した。

室温酢酸系の Cole-Cole プロットでは, 高周波数側 の小さな円弧之低周波数側の大きな円弧の二つの歪んだ 半円が得られ, 電荷移動反応と不動態皮膜形成反応の支 配を受け, 電極表面は $C_{\mathrm{dl}}$ と皮膜容量 $C_{\mathrm{f}}$ を持つコンデ ンサーと $R_{\mathrm{sol}}$ と $R_{\mathrm{ct}}$ 之皮膜抵抗 $R_{\mathrm{f}}$ からなる等価回路が 存在すると想定される。このとき得られた皮膜は不動態 皮膜でなく保護性の悪い電導度の高い塩沈殿皮膜9) で腐 食抑制にほとんど寄与しないと考えられる。腐食速度の 最も小さい硫酸添加系では $R_{\mathrm{f}}$ が $52 \Omega \mathrm{cm}^{2}$ と最も大き く, 腐食速度の大きな過塩素酸リチウム添加系では 17 $\Omega \mathrm{cm}^{2}$, 水添加系では $8.9 \Omega \mathrm{cm}^{2}$ と小さな值を示した。 一方腐食速度がきわめて大きな硝酸添加系では小さな円 弧が一つだけ得られ，電極表面は $C_{\mathrm{d} 1}$ を持つコンデン サーと $R_{\mathrm{ct}}$ 之 $R_{\mathrm{sol}}$ からなる等価回路が考えられる。

\subsection{5 表面解析}

室温酢酸系に 1 日間浸漬した試験片表面のXPS によ る解析結果では， $\mathrm{O}_{1 \mathrm{~s}}, \mathrm{Fe}_{2 \mathrm{p} 3 / 2}$ および $\mathrm{C}_{1 \mathrm{~s}}$ の内殸電子の 結合エネルギーと光電子の検出強度の関係を Fig. 5 (1) に示す。

$\mathrm{C}_{1 \mathrm{~s}}$ スペクトルでは，エッチング時間 0 分の試験片最 表層にピークが現れ，時間の経過と共にピークは急激に 小さくなった。このピークは $285 \mathrm{eV}$ に現れ，炭素結合 の種類の中で $\left(-\mathrm{CH}_{2}-: 285.0 \mathrm{eV}\right)^{22)}$ に相当すると考 えられる。炭素結合が試験片の最表層とその下層から検 出したため, 酶酸に浸漬後の鋼材表面には酶酸イオンと 


\section{(1) $\mathrm{CH}_{3} \mathrm{COOH}$}

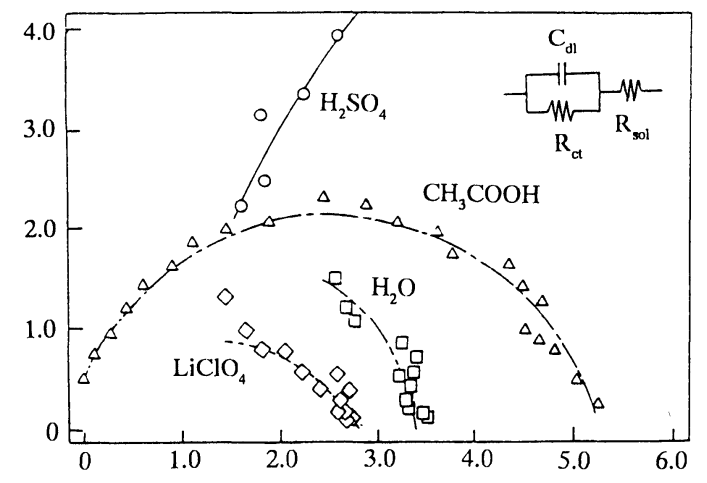

(2) $\mathrm{C}_{2} \mathrm{H}_{5} \mathrm{OH}$

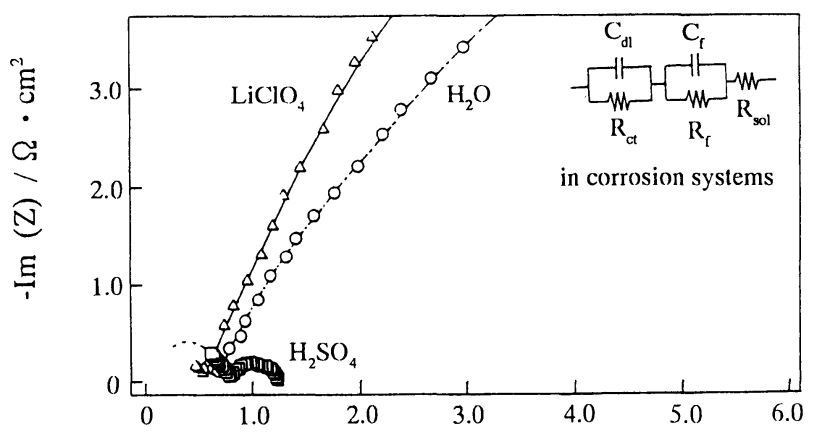

(3) $\mathrm{CH}_{3} \mathrm{COCH}_{3}$

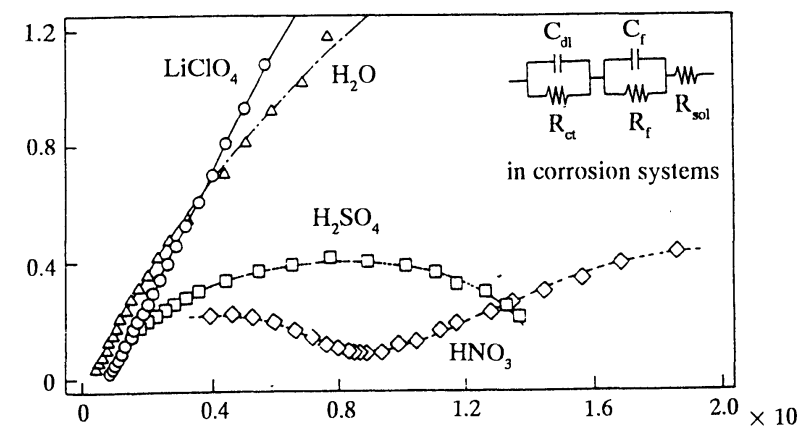

$\operatorname{Re}(\mathrm{Z}) / \Omega \cdot \mathrm{cm}^{2}$

Fig. 4 Cole-Cole plots of SS 400 in various solutions at b. p.

鉄イオンが結合した酶酸鉄を含む層が存在していること が考えられる。

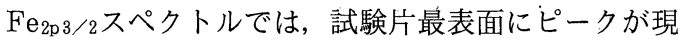
れなかった。0.5 分後の $709 \mathrm{eV}$ にピークが現れ, $\mathrm{FeO}$ $(709.2 \mathrm{eV})^{22)}$ と一致したため $\mathrm{FeO}$ が存在したと考えら れる。さらにエッチングしていくと 1.5 分後から 707 $\mathrm{eV}$ 付近にピークが現れ, 金属 $\mathrm{Fe}(706.6 \mathrm{eV})^{22)}$ の存在 が確認できる。他の酸化鉄, 水酸化鉄等は観察されな
かった。

$\mathrm{O}_{1 \mathrm{~s}}$ スペクトルでは, 試験片最表面で 532 $\mathrm{eV}$ 付近にピークが現れ, 水酸化物の酸素 $(\mathrm{M}-\mathrm{OH}: 531.4 \mathrm{eV})^{23)}$ に相当すると考えら れる。エッチングを続けると 0.5 分後から $530 \mathrm{eV}$ にピークが現れ, 酸化物の酸素に相 当すると予想される。この酸化物は 1.0 分 後まで明確に検出され，それ以後急激に消失 していった。

以上のことから最表層には, 酢酸鉄と水酸 化鉄から構成される皮膜が存在し，その下層 に酸化鉄 $\mathrm{FeO}$ から構成される皮膜が存在し, 内部は金属鉄のままであると考えられる。

\section{2 エタノール系}

\subsection{1 腐食重量減試験}

沸点エタノール系（Fig.1 (2)）では，エ タノール一成分中での SS 400 鋼の腐食は進 行せず，試験片表面は浸漬前と同じ光沢を 保っていた。この系に硫酸を添加すると腐食 は著しく進行し, 腐食速度は硫酸の濃度の増 加とともに増大して, 最高濃度の $1.0 \mathrm{~N}$ で は $1.5 \times 10^{4} \mathrm{mdd}$ となった。このことはエ夕 ノール（酸解離定数 $\mathrm{p} K_{\mathrm{a}}=16.00^{16)}$ ) が，水

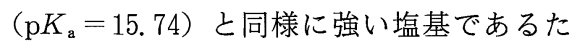
め, 酸のプロトン解離がほぼ完全に進行し腐 食速度が増加したと考えられる。

$$
\begin{aligned}
& \mathrm{H}_{2} \mathrm{SO}_{4}+\mathrm{C}_{2} \mathrm{H}_{5} \mathrm{OH} \\
& \stackrel{\rightleftarrows}{\rightleftarrows} \mathrm{C}_{2} \mathrm{H}_{5} \mathrm{OH}_{2}{ }^{+}+\mathrm{HSO}_{4}{ }^{-}
\end{aligned}
$$

副反応として硫酸添加系では硫酸エステル の形成 ${ }^{24)}$ が考えられる。この反応は，炭素一 酸素結合が開裂せずかなり容易に進行する。 反応後も $-\mathrm{OH}$ の $\mathrm{H}^{+}$が解離してかなりの腐 食性をもつと予想される。

$$
\begin{aligned}
& \mathrm{C}_{2} \mathrm{H}_{5} \mathrm{OH}+\mathrm{HO}-\mathrm{SO}_{2}-\mathrm{OH} \\
& \stackrel{\mathrm{C}}{2} \mathrm{H}_{5}-\mathrm{O}-\mathrm{SO}_{2}-\mathrm{OH}+\mathrm{H}_{2} \mathrm{O}
\end{aligned}
$$

硝酸を添加すると，腐食は硫酸添加系より もっと激しく進行した。腐食速度は最高濃度 の $1.0 \mathrm{~N}$ のとき $8.0 \times 10^{4} \mathrm{mdd}$ となった。 このことはエタノール中で硝酸が強酸として 作用した上に，強い酸化剂として働いたことによると考 えられる。

硝酸添加系ではエタノールが硝酸と反応して硝酸アル キルを与える ${ }^{25)}$ 。

$$
\mathrm{C}_{2} \mathrm{H}_{5} \mathrm{OH}+\mathrm{HO}-\mathrm{NO}_{2} \longrightarrow \mathrm{CH}_{3} \mathrm{C}-\mathrm{O}-\mathrm{NO}_{2}+\mathrm{H}_{2} \mathrm{O}
$$

この物質は，酸性の水素が残っていないため腐食反応 に寄与しないと考えられる。 
(1) $\mathrm{CH}_{3} \mathrm{COOH}$
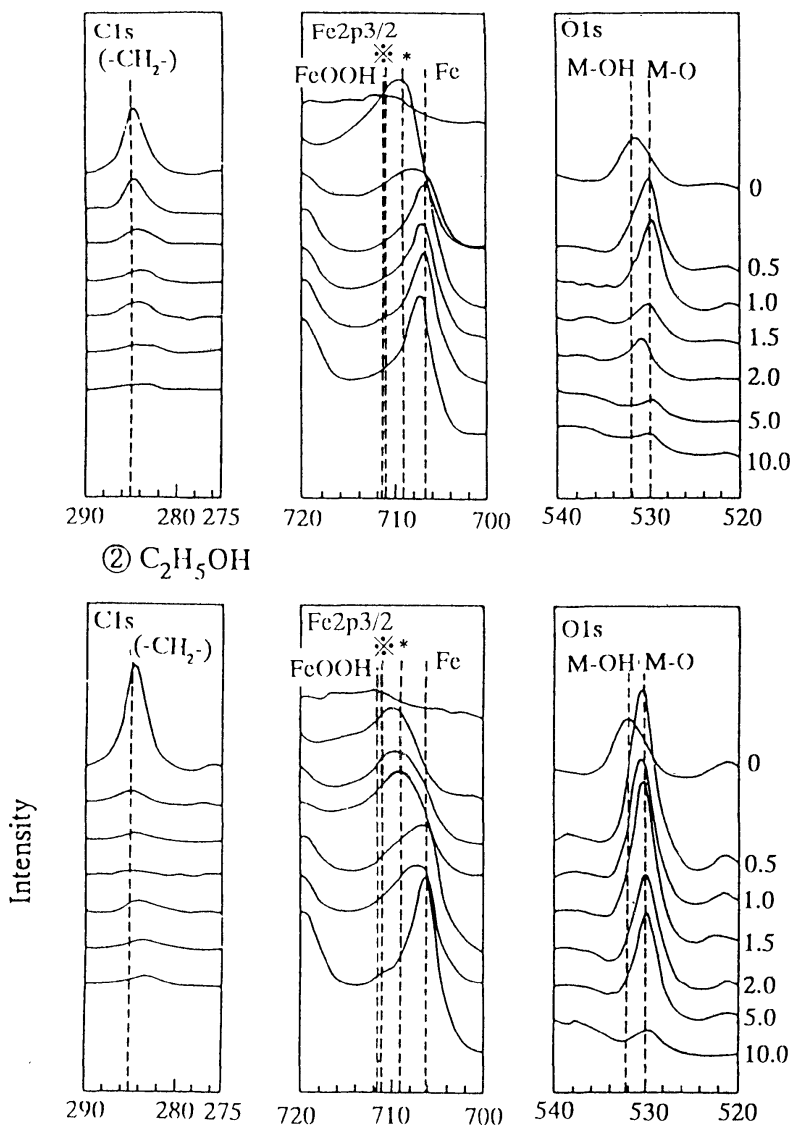

(3) $\mathrm{CH}_{3} \mathrm{COCH}_{3}$
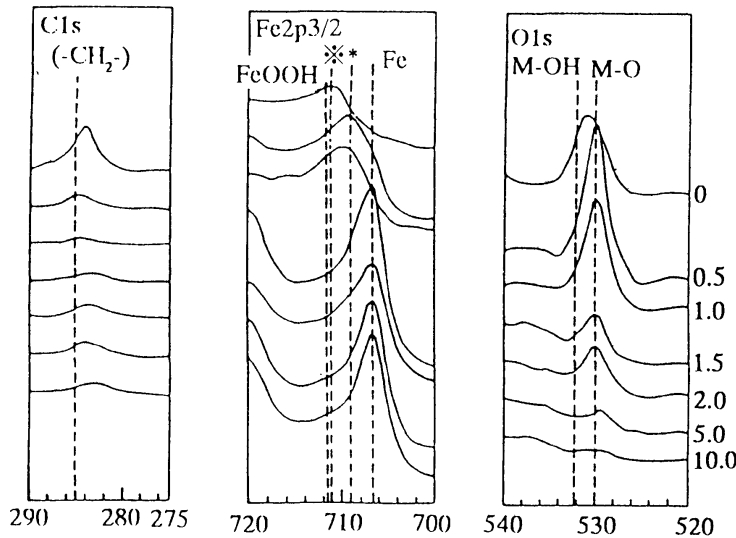

Binding energy (cV)

Fig. 5 Surface analyses of SS 400 in various solutions at $25^{\circ} \mathrm{C}$ by XPS.

過塩素酸リチウムおよび水添加系では，一成分系と同 じくいずれの系でも腐食速度は $0.0 \mathrm{mdd}$ 之腐食が進行 せず，これらの物質はエタノール中で腐食加速因子とし
* $\mathrm{FeO}$

$※ \mathrm{Fc}_{2} \mathrm{O}_{3}$

$\mathrm{Fe}_{3} \mathrm{O}_{4}$

て作用しない。

室温エ夕ノール系では, 腐食挙動は沸 点系と同じ挙動を示したが, 温度が低い ため腐食速度は沸点系よりかなり小さな 值となった。硫酸と硝酸の添加最高濃度 $(1.0 \mathrm{~N})$ でのそれぞれの腐食速度は 1.0 $\times 10^{3} \mathrm{mdd}$ と $7.8 \times 10^{3} \mathrm{mdd}$ を示した。 このことから反応機構は沸点系と類似し ていると考えられる。

\section{2.2 分極曲線測定}

沸点エタノール系（Fig. 2 (2)）で は, いずれのアノード分極曲線にも不動 態域が観測された。特に腐食が抑制され た水添加系では約 $-1.2 \mathrm{~V}$ から+0.1 V vs. $\mathrm{Ag} / \mathrm{Ag}^{+}$まで, 過塩素酸リチウム添 加系では約ー1.1 Vから+0.5 V にいた る広範な電位領域で, 不動態域が観察さ れた。この不動態保持電流は $10^{-2} \mathrm{~mA}$ ・ $\mathrm{cm}^{-2}$ 之極めて小さく, 試験片は不動態 化によってアノード溶解反応が抑制され ている。Kerry ら ${ }^{26)}$ は溶媒の化学吸着 による不動態化を指摘している。

水添加系では約 $+0.1 \mathrm{~V}$, 過塩素酸リ チウム添加系では約 $+0.5 \mathrm{~V}$ から電流密 度が急増する。貴な電位領域では不動態 皮膜が破壊され腐食が進行し ${ }^{9)}$, この電 位に保った試験片は灰白色に変色してい た。また水分を添加することにより卑な 電位で腐食が始まり，アノード分極曲線 の電流密度が上昇することが観察され た。この腐食は，(12)式27)のような過塩 素酸イオンの酸化により不動態皮膜が破 壊されたと考えられる。

$$
\begin{array}{r}
\mathrm{ClO}_{4}{ }^{-} \longrightarrow \mathrm{ClO}_{4}+\mathrm{e}^{-} \\
\quad \longrightarrow \mathrm{ClO}_{2}+2 \mathrm{O}_{\text {ads. }}
\end{array}
$$

硫酸添加系では約 $+0.5 \mathrm{~V}$ から+0.9 V vs. $\mathrm{Ag} / \mathrm{Ag}^{+}$の範囲, 硝酸添加系では 約+1. $1 \mathrm{~V}$ より貴な電位でアノード反応 抑制領域が観察された。この貴な電位の 抑制領域では, エタノール中で硫酸およ び硝酸が強酸として作用するが, 皮膜生 成速度が皮膜溶解速度に比べて大きいた め塩皮膜を形成する。しかし自然電位で はアノード・カソード反応いずれも進行 し，腐食抑制に寄与しないと考えられる。

室温エタノール系では，いずれのアノード分極曲線も 沸点系と同じ形状を示し, 同じ腐食機構を示していると 
考えられる。水添加系では約 $-1.0 \mathrm{~V}$ から+0.2 V vs. $\mathrm{Ag} / \mathrm{Ag}^{+}$まで, 過塩素酸リチウム添加系では約 $-0.9 \mathrm{~V}$ から+0.2 Vにいたる広範な電位領域で不動態域が観察 された。硫酸添加系では約+0.1 Vから $1.0 \mathrm{~V}$ vs. $\mathrm{Ag} /$ $\mathrm{Ag}^{+}$の範用, 硝酸添加系では約 $+0.1 \mathrm{~V}$ から+0.4 V の 電位領域でアノード反応抑制領域が観察された。

\section{2.3 自然電極電位測定}

沸点エタノール系（Fig. 3 (2)）では, 硝酸および硫 酸添加系の自然電極電位は急速に貴な電位側に移行し, 24 時間後に硫酸添加系で $-0.86 \mathrm{~V}$, 硝酸添加系で $-0.70 \mathrm{~V}$ 之活性化支配領域に達した。このことから活 性溶解の進行が考えられる。一方水および過塩素酸リチ ウム添加系の自然電位は, 徐々に貴な電位に移行し, 水 添加系で-0.97 V, 過塩素酸リチウム添加系では $-0.91 \mathrm{~V}$ と前述の分極曲線（Fig. 2 (2)）の不動態域上 に存在し，不動態化による腐食抑制が考えられる。

室温エタノール系では沸点系と同じ傾向が現れ，硝酸 および硫酸添加系の自然電極電位は急速に貴な電位側に 移行し, 24 時間後に硫酸添加系で $-0.87 \mathrm{~V}$, 硝酸添加 系でー0.74 V と活性化支配領域に達した。このことか ら活性溶解の進行が考えられる。一方水および過塩素酸 リチウム添加系の自然電位は, 徐々に貴な電位に移行 し, 水添加系で $-0.62 \mathrm{~V}$, 過塩素酸リチウム添加系で $-0.56 \mathrm{~V}$ と不動態域に達したので不動態化による腐食 抑制が考えられる。

一般に，自然電極電位が貴な電位側に移行することは 保護皮膜形成と補修が進行し腐食が抑制されることを示 す。しかし電極電位は金属表面の応力, 荒さ, 傷, 切断 部周辺, 形状, 表面皮膜などの金属側の因子および溶液 のイオン濃度, 通気状態, 形状, 表面皮膜などの環境側 の因子によって影響を受ける28)ので, 測定した自然電極 電位は完全に一致することはない。

\section{2.4 交流インピーダンス測定}

沸点エタノール系における Cole-Cole プロット(Fig. 4 (2) では, 硫酸添加系で高周波数側の大きな円弧の一 部と低周波数側の小さな円弧が得られ, 電荷移動反応と 皮膜形成反応の支配を受けている。このとき得られた皮 膜は不動態皮膜でなく保護性の悪い塩皮膜と考えられ る。一方, 水および過塩素酸リチウム添加系では, 高周 波数側に円弧はなく, 低周波数側に大きな円弧の一部が 得られた。この円弧は抵抗の大きな皮膜形成に対応し， 溶液中の水分によって鋼板表面に酸化物が形成すること を示している。腐食速度が大きい硫酸添加系では皮膜抵 抗が $3.0 \times 10^{-1} \Omega \mathrm{cm}^{2}$ と最も小さく, 腐食が進行しな かった水および過塩素酸リチウム添加系ではそれぞれ $2.9 \times 10^{2} \Omega \mathrm{cm}^{2}$ と $2.3 \times 10^{2} \Omega \mathrm{cm}^{2}$ と大きな值を示し た。
室温エタノール系では, 沸点系と同様な結果が得ら れ, 同じ腐食機構が起きていると考えられる。腐食速度 が大きい硫酸および硝酸添加系では, 皮膜抵抗はそれぞ れ $8.8 \Omega \mathrm{cm}^{2}, 1.1 \Omega \mathrm{cm}^{2}$ と小さく, 腐食が進行しな かった水および過塩素酸リチウム添加系では，それぞれ $1.1 \times 10^{2} \Omega \mathrm{cm}^{2}, 1.2 \times 10^{2} \Omega \mathrm{cm}^{2}$ と大きな值を示した。 また硫酸添加系では, 沸点系より皮膜抵抗は増大し, 腐 食速度の減少に対応した。

金属の不動態化機構は次の 4 種類に分類できる ${ }^{9)}$ : （a）空気形成皮膜，（b）塩皮膜，（c）溶媒の化学吸着,

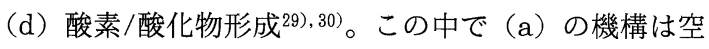
気形成皮膜が実験下の溶液中で安定である必要がある が, 測定前に試験片の還元を行ったために消失したと考 えられる。（b）の機構は活性溶解により金属カチオン と溶液とからのアニオンから構成された塩が, 金属表面 に過飽和される必要があるが, 溶液からアニオンの供給 がないので除かれる。（c）の機構は溶媒分子が, 化学 的あるいは電気化学的な吸着によって金属表面に接触す る必要があるが, インピーダンス測定では皮膜形成を示 す半円の一部が観察されただけで吸着を示す軌跡は観察

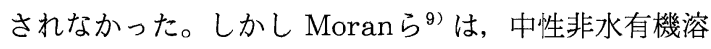
媒中で大部分の金属は溶媒の吸着によって不動態化し，

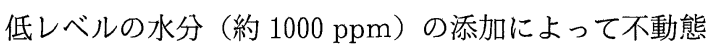
化機構が劣化されることを指摘している。そこで吸着溶 媒皮膜による不動態化が考えられる。(d) の機構は酸 素あるいは, 酸素を含むアニオンが表面上のカチオン金 属に結合し, 三次元構造の酸素/酸化物皮膜を形成す る。有機溶媒の酸素原子は炭素原子之強く結び付けら れ, 酸化皮膜形成のために解離することはあり得ない。 よって完全な非水有機溶媒ではこの機構は起こらない。 しかし支持電解質を加えた溶液から微量の水を取り除く ことは困難で, 酸化物を形成する ${ }^{9)}$ 。水添加エタノール 系では加えた水分により酸化され, 一方過塩素酸リチウ ム添加系では, 溶液中に残存する約 $400 \mathrm{ppm}$ の水分に よって酸化されたことが考えられる。

以上より鋼材表面の酸化皮膜と吸着溶媒皮膜によって 鋼材表面は不動態化され腐食抑制されたと推測される。

\section{2.5 表面解析}

室温エタノール系に 1 日間浸漬した試験片表面の XPS による解析結果（Fig. 5 (2)）では， $\mathrm{O}_{1 \mathrm{~s}}, \mathrm{Fe}_{2 \mathrm{p} 3 / 2}$ および $\mathrm{C}_{1 \mathrm{~s}}$ の内殻電子の結合エネルギーと光電子の検出 強度の関係を示す。

$\mathrm{C}_{1 \mathrm{~s}}$ スペクトルでは, エッチング時間 0 分の試験片最 表層にピークが現れた。このピークは $285 \mathrm{eV} に$ 現れ， 炭素結合の種類の中で $\left.\left(-\mathrm{CH}_{2}-: 285.0 \mathrm{eV}\right)^{22}\right)$ に相当 すると考えられる。炭素結合が試験片の最表面から検出 したため, エ夕ノール系に浸漬後の鋼材表面に溶媒分子 
が吸着されたと考えられる。

$\mathrm{Fe}_{2 \mathrm{p} 3 / 2}$ スペクトルでは, 試験片最表面でピークが現 れず, 同定は困難であった。 0.5 分後から 1.5 分後まで $709 \mathrm{eV}$ にピークが現れ, $\mathrm{FeO}(709.2 \mathrm{eV})^{22)}$ と一致し たため $\mathrm{FeO}$ が存在したと考えられる。さらにエッチン グしていくと, 2.0 分後から $707 \mathrm{eV}$ 付近にピークが現 れ, 金属 $\mathrm{Fe}(706.6 \mathrm{eV})^{22)}$ の存在が確認できる。他の 酸化鉄，水酸化鉄等は観察されなかった。

$\mathrm{O}_{1 \mathrm{~s}}$ スペクトルでは, 試験片最表面で $532 \mathrm{eV}$ 付近に ピークが現れ, 水酸化物の酸素 $(\mathrm{M}-\mathrm{OH}: 531.4 \mathrm{eV})^{23)}$ に相当すると考えられる。この水酸化物はエ夕ノール中 に残存する水分によって形成が予想される。エッチング を続けると 0.5 分後から 1.5 分後にいたる範囲におい て $530 \mathrm{eV}$ に強いピークが現れ，さらに 2.0 分後から 5.0 分後まで徐々に弱いピークが現れ, 酸化物の酸素 $(\mathrm{M}-\mathrm{O}: 530.0 \mathrm{eV})^{23)}$ に相当すると考えられる。

以上のことから鋼板表面にエタノール分子が吸着され 不動態皮膜を形成し, 次に, 水酸化鉄から構成される皮 膜が存在し，その下層に酸化鉄 $\mathrm{FeO}$ から構成される皮 膜が存在し，さらに下層に金属 $\mathrm{Fe}$ 之酸化鉄から構成さ れる皮膜が存在し，内部は金属鉄のままであることが推 測される。

\section{3 ジェチルアミン系}

\subsection{1 腐食重量減試験}

沸点ジエチルアミン系 (Fig. 1 (3)) では, ジエチル アミン一成分中での SS 400 鋼の腐食は進行せず, 試験 片表面は浸漬前と同じ光沢を保っていた。水および過塩 素酸リチウム添加系の腐食速度も $0.10 \mathrm{~N}, 0.5 \mathrm{~N}, 1.0$ $\mathrm{N}$ の各濃度で腐食はまったく進行せず，これらの物質 はジエチルアミン系で腐食促進物質として作用しない。 硫酸および硝酸添加系は, 溶媒と反応して不溶性の沈殿 を生じたため結果は得られなかった。

室温系でも同じ結果が得られ，腐食機構は沸点系と等 しいと考えられる。ジェチルアミン系では，不動態化の 中で次のような機構が考えられる。（a）空気形成皮膜 の機構は, 空気形成皮膜が実験下の溶液中で安定である 必要があるが, 重量減試験の前に, 鋼材の還元を実行で きなかったためにそのまま残存する。（b）塩皮膜形成 は, 溶液からアニオンの供給がないので除く。（c）溶 媒の化学吸着は, アミン分子中の電気陰性度の高い窒素 原子が, 孤立電子対を鉄の空の $\mathrm{d}$ 軌道と共有するため, 金属表面に接触し化学吸着をしている ${ }^{31)}$ 。

$: \mathrm{NH}_{2} \mathrm{R}+\mathrm{M} \rightarrow \mathrm{M}: \mathrm{NH}_{2} \mathrm{R}$

そこで溶媒分子の吸着による不動態化が考えられる。

（d）酸素/酸化物皮膜形成は，支持電解質を加えた溶液 から微量の水を取り除くことは困難で，残存する水分に より不動態化される。水分子の吸着はジエチルアミン分
子と競合する。水分子のモル比はアミンよりはるかに少 ないが金属表面に特異吸着し，わずかな水分濃度でも酸 化皮膜を形成する。そこで水および過塩素酸リチウム添 加系では溶液中に残存する微量水分による不動態化が想 定される。

\section{4 アセトン系}

\section{4. 1 腐食重量減試験}

沸点アセトン系（Fig. 1 (4)）では，アセトン一成分 中の SS 400 鋼は腐食が進行せず, 試験片表面は浸漬前 と同じ光沢を保っていた。この系に硫酸を添加すると， 腐食速度は $0.02 \mathrm{~N}$ のとき $2.2 \mathrm{mdd}, 0.10 \mathrm{~N}$ のとき 3.3 $\mathrm{mdd}, 0.5 \mathrm{~N}$ のとき $4.3 \mathrm{mdd}, 1.0 \mathrm{~N}$ のとき $20 \mathrm{mdd}$ となり, ある程度腐食が進行したが, 酢酸およびエ夕 ノール系の腐食速度に比べて著しく小さな值を示した。 このことはアセトンはエタノールと異なり強い塩基性を 示さないため, 水素イオンの解離があまり進行しないと 考えられる。副反応としてアセトンが硫酸によって脱水 する反応が考えられるが，反応は複雑と考えられ生成物 質は同定できなかった。

硝酸を添加すると，浸漬後溶液に溶解できない腐食生 成物が約 $1 \mathrm{~mm}$ の厚いスケール層として鋼板表面に付着 していた。この腐食は硫酸添加系より激しく進行し, 腐 食速度は $0.02 \mathrm{~N}$ のとき $6.2 \times 10^{2} \mathrm{mdd}, 0.10 \mathrm{~N}$ のとき $1.5 \times 10^{3} \mathrm{mdd}, \quad 0.5 \mathrm{~N}$ のとき $6.9 \times 10^{3} \mathrm{mdd}, 1.0 \mathrm{~N}$ の とき $1.6 \times 10^{4} \mathrm{mdd}$ となった。このことは, 硝酸のアセ トン中における強い酸化剂としての作用による。硝酸系 のスケール層は 2 層からなり, 外層の赤褐色の軟質な層 之内層は黒色のやや硬質な層から形成され，浸漬直後は 急速に腐食が進行するが, 浸漬時間が経過するにつれて スケール層形成により腐食速度は浸漬直後から減少した と考えられる。

水および過塩素酸リチウム添加系での腐食はほとんど 進行せず，各濃度 $(0.02,0.10,0.5,1.0 \mathrm{~N})$ での腐 食速度はすべてゼロであった。これらの物質はエタノー ル系同様アセトン中でも腐食加速因子として作用しな い。

室温アセトン系では，腐食挙動は沸点系と同じ挙動を 示したが，温度が低いため腐食速度は沸点系よりかなり 小さな值となり, 硫酸添加系で腐食速度は $0.02 \mathrm{~N}$ のと き $0.38 \mathrm{mdd}, 0.10 \mathrm{~N}$ のとき $1.5 \mathrm{mdd}, 0.5 \mathrm{~N}$ のとき $2.4 \mathrm{mdd}, 1.0 \mathrm{~N}$ のとき $4.0 \mathrm{mdd}$ となった。硝酸添加 系ではスケール層が付着したが， $0.02 \mathrm{~N}$ のとき $3.4 \times$ $10^{2} \mathrm{mdd}, 0.10 \mathrm{~N}$ のとき $1.2 \times 10^{3} \mathrm{mdd}, 0.5 \mathrm{~N}$ のとき $3.1 \times 10^{3} \mathrm{mdd}, 1.0 \mathrm{~N}$ のとき $5.6 \times 10^{3} \mathrm{mdd}$ となり同 様の傾向を示した。このことから反応機構は沸点系と等 しいと考えられる。 


\section{4.2 分極曲線測定}

沸点アセトン系 (Fig. 2 (3) ) では, 硫酸, 水および 過塩素酸リチウム添加系のアノード分極曲線に不動態域 が観測された。腐食が抑制された水添加系では約 -1.0 $\mathrm{V}$ から-0.1 V vs. $\mathrm{Ag} / \mathrm{Ag}^{+}$まで, 過塩素酸リチウム添 加系では約 $-0.6 \mathrm{~V}$ から $+0.5 \mathrm{~V}$ にいたる広範な電位領 域で不動態域が観察された。この不動態保持電流は約 $10^{-1}$ から $10^{1} \mathrm{~mA} \cdot \mathrm{cm}^{-2}$ と比較的大きいが, 試験片は不 動態化によってアノード溶解反応が抑制されていると考 えられる。過塩素酸リチウム添加系の方が水添加系よ り, 広範な電位領域にわたり保持電流密度が低い不動態 域が現れた。またエタノール系と同様, 水分の添加によ り腐食が開始する電位が卑な電位へ移行し, 不動態保持 電流密度の上昇が観察された。

硫酸添加系では約 $-0.4 \mathrm{~V}$ から $+1.1 \mathrm{~V}$ の範囲で不動 態域が観察された。この不動態化機構は（b）塩皮膜形 成で, 活性溶解により金属カチオンと溶液からのアニオ ン $\left(\mathrm{SO}_{4}{ }^{2-}\right)$ から構成される硫酸鉄は皮膜溶解速度が小 さいため, 腐食速度が小さな值を示したと考えられ る27)。酸性有機溶液中では溶媒分子吸着は起こりにく く, 酸化皮膜は溶解されるため (c)（d）の不動態化機 構は除かれる。

腐食速度が著しく大きな硝酸添加系では, 不動態域等 のアノード・カソード反応抑制領域は観察されず, 活性 溶解が進行したことがわかる。腐食重量減試験で観察さ れたスケール層の影響は, 分極曲線測定で観察されな かった。

室温アセトン系では，いずれのアノード分極曲線も沸 点系と同じ形状を示し, 同じ腐食機構が起きていると考 えられる。水添加系では約 $-0.9 \mathrm{~V}$ から $0.0 \mathrm{~V}$ まで, 過 塩素酸リチウム添加系では約 $-0.4 \mathrm{~V}$ から $+0.7 \mathrm{~V}$ にい たる広範な電位領域で不動態域が観察され, 硫酸添加系 では約 $-0.4 \mathrm{~V}$ から $+1.3 \mathrm{~V}$ の範囲でアノード反応抑制 域が観察された。

\section{4.3 自然電極電位測定}

沸点アセトン系 (Fig. 3 (3) ) では, 硫酸添加系の自 然電極電位は急速に貴な電位側に移行し, 24 時間後に - $0.64 \mathrm{~V}$ とアノード反応抑制領域に達した。このこと から表面に形成された皮膜による腐食抑制が考えられ る。硝酸添加系では電位は急速に貴な電位側に移行し一 度安定したが, 数時間後さらに貴な電位に移行し 24 時 間後に+0.24. V となった。一方水および過塩素酸りチ ウム添加系の自然電位は, 徐々に貴な電位側に移行し, 水添加系で $-0.75 \mathrm{~V}$, 過塩素酸リチウム添加系では $-0.90 \mathrm{~V}$ と不動態域に達し, 不動態化による腐食抑制 が想定される。

室温アセトン系では沸点系と同じ傾向が現れた。硫酸
添加系の自然電極電位は 24 時間後に $-0.66 \mathrm{~V}$ とアノー ド反応抑制領域に達し, 硝酸添加系の電位は $+0.08 \mathrm{~V}$ となった。一方, 水および過塩素酸リチウム添加系では それぞれ $-0.60 \mathrm{~V},-0.66 \mathrm{~V}$ と不動態域に達し, 沸点 系と同じ機構が考えられる。

\subsection{4 交流インピーダンス測定}

沸点アセトン系における Cole-Coleプロット (Fig. 4 (3)）では，24 時間後に自然電位に設定して測定した。 硫酸添加系では低周波数側に円弧が得られ, 皮膜形成反 応の支配を受けているが，このとき得られた皮膜は酸化 物や吸着溶媒分子による不動態皮膜でなく保護性の悪い 硫酸鉄皮膜と考えられる。硝酸添加系では高周波数側と 低周波数側に円弧の一部が得られ, 電荷移動反応と皮膜 形成反応の支配を受けていると考えられる。このとき得 られた皮膜は，鋼板表面に形成されていた硝酸鉄の塩皮 膜で，この皮膜形成によって抵抗が，比較的大きな值を 示したと考えられる。

水および過塩素酸リチウム添加系では, 高周波数側に は円弧はなく低周波数側の大きな円弧の一部が得られ た。この円弧は抵抗の大きな皮膜形成に対応し，不動態 化が進行したことを示している。腐食が進行した硫酸添 加系では皮膜抵抗が $2.0 \times 10 \Omega \mathrm{cm}^{2}$, 硝酸添加系では $6.6 \times 10 \Omega \mathrm{cm}^{2}$ と大きく, 腐食が進行しなかった水およ び過塩素酸リチウム添加系では, それぞれ $4.1 \times 10^{2} \Omega$ $\mathrm{cm}^{2}$ と $1.7 \times 10^{3} \Omega \mathrm{cm}^{2}$ と大きな值を示した。

室温アセトン系では, 沸点系より温度が低いため皮膜 溶解速度が小さく, 大きな皮膜抵抗を示した。腐食が進 行した硫酸および硝酸添加系では皮膜抵抗はそれぞれ $1.2 \times 10^{3} \Omega \mathrm{cm}^{2}, 9.2 \times 10 \Omega \mathrm{cm}^{2}$ と小さく，腐食が進行 しなかった水および過塩素酸りチウム添加系では，それ ぞれ $2.7 \times 10^{3} \Omega \mathrm{cm}^{2}$ と $6.7 \times 10^{3} \Omega \mathrm{cm}^{2}$ と大きな值を示 した。

\section{4.5 表面解析}

室温アセトン系に 1 日間浸漬した試験片表面の XPS による結果（Fig. 5 (3)）では， $\mathrm{O}_{1 \mathrm{~s}}, \mathrm{Fe}_{2 \mathrm{p} 3 / 2}$ および $\mathrm{C}_{1 \mathrm{~s}}$ の内殼電子の結合エネルギーと光電子の検出強度の関係 を示す。

$\mathrm{C}_{1 \mathrm{~s}}$ スペクトルでは, エッチング時間 0 分の試験片最 表層にピークが現れた。このピークは $284 \mathrm{eV}$ 付近に現 れ, 炭素結合 $\left(-\mathrm{CH}_{2}-: 285.0 \mathrm{eV}\right)^{22)}$ からシフトした と考えられる。炭素結合が試験片の最表面から検出した ため, 浸漬により鋼材表面に吸着されたアセトン分子が 存在すると考えられる。

$\mathrm{Fe}_{2 \mathrm{p} 3 / 2}$ スペクトルでは, 試験片最表面で $711 \mathrm{eV}$ に ピークが現れ $\mathrm{Fe}_{2} \mathrm{O}_{3}(710.7 \mathrm{eV})^{22)}$ と $\mathrm{Fe}_{2} \mathrm{O}_{4}(711.1$ $\mathrm{eV})^{22)}$ の存在が考えられる。0.5 分後から 1.0 分後まで $709 \mathrm{eV}$ にピークが現れ $\mathrm{FeO}(709.2 \mathrm{eV})^{22)}$ と一致し, 
$\mathrm{FeO}$ の存在が予想される。さらにエッチングしていく と 1.5 分後から $707 \mathrm{eV}$ 付近にピークが現れ金属 $\mathrm{Fe}$ $(706.6 \mathrm{eV})^{22)}$ の存在が確認できる。

$\mathrm{O}_{1 \mathrm{~s}}$ スペクトルでは, 試験片最表面で $531 \mathrm{eV}$ 付近に ピークが現れ，水酸化物の酸素 $(\mathrm{M}-\mathrm{OH}: 531.4 \mathrm{eV})^{23)}$ 之酸化物の酸素 $(\mathrm{M}-\mathrm{O}: 530.0 \mathrm{eV})^{23)}$ に相当すると考え られる。この水酸化物はアセトン中に残存する水分に よって形成されたと考えられる。エッチングを続けると 0.5 分後から 1.0 分後にいたる範囲にわたって $530 \mathrm{eV}$ に強いピークが現れ，さらに 1.5 分後から 2.0 分後ま で弱いピークが現れ，酸化鉄の酸素に相当すると考えら れる。この酸化鉄は，アセトン系では腐食が進行しない ため, 浸漬以前に空気中の酸素によって形成された皮膜 と予想される。

以上のことから鋼板表面上にアセトン分子が吸着され 不動態皮膜を形成し，次に，水酸化鉄と酸化鉄 $\mathrm{Fe}_{2} \mathrm{O}_{3}$ 乞 $\mathrm{Fe}_{3} \mathrm{O}_{4}$ から構成される皮膜が存在し； その下層に酸 化鉄 $\mathrm{FeO}$ から構成される皮膜が存在し, 内部は金属鉄 のままであると考えられる。

\section{4. 結 論}

各種有機溶液中の鋼材（SS 400）の腐食挙動について 検討したところ次の結論を得た。

\section{（腐食重量減試験）}

1. 有機溶媒中では, 硫酸・硝酸などの添加により, 水素イオン濃度が増大するときおよび酸化剂として作用 するとき腐食が著しく促進された。

2. 酢酸系のように腐食が進行する系では, 水や過塩 素酸リチウムの添加は, 系に存在する水素イオン濃度の 増大の作用や酸化剂としての作用がある。エ夕ノール, アセトン系のように腐食が進行しない系では, 水や過塩 素酸リチウムを添加してもこれらが腐食加速因子として 作用しない。

3. 硫酸のような強酸を添加した時, エタノールのよ うに強い塩基性の溶媒中では腐食速度が増大し, 酢酸の ように弱い塩基性の溶媒中では減少した。

（分極曲線, 自然電位の測定）

4. 腐食が抑制された系では，アノード分極曲線上に 広範な電位領域にわたり不動態域が観察され，自然電位 は不動態域上に存在した。一方, 腐食が著しく進行した 系では，分極曲線上に不動態域は観察されず自然電位は 活性溶解域上に存在した。

5. エタノール，アセトン系では水を添加すると，不 動態域の電流密度が増加する，このことは皮膜の劣化に よると考えられる。

\section{（インピーダンス测定）}

6. 測定より，沸点酢酸系のように腐食が著しく進行
している系では電荷移動過程のみ現れ，腐食の進行が弱 くなるにつれて皮膜形成反応が支配的になり，腐食が進 行しなかった系では大きな皮膜抵抗を持つ皮膜が現れ た。

7. 有機溶媒中では，不動態皮膜の形成によって腐食 が抑制された。このとき観察される皮膜は, 完全に腐食 が抑制される不動態皮膜とある程度抑制される塩皮膜に よる不動態皮膜が存在すると考えられる。

8. 不動態によって腐食が完全に抑制されている系で も, 溶液系の条件により, 皮膜抵抗は最小 $1.1 \times 10^{2} \Omega$ $\mathrm{cm}^{2}$ から最大 $6.7 \times 10^{3} \Omega \mathrm{cm}^{2}$ と大きく变化した。

（表面解析）

9. 有機溶媒中の鉄水酸化物皮膜は，残存する微量水 分の消費により形成され，塩による皮膜形成は，鉄イオ ンのカチオンと酢酸イオンや硫酸イオンのアニオンから 構成される酢酸鉄や硫酸鉄と考えられる。

10．腐食が進行した系では，鋼板表層に塩皮膜が存在 し，進行しない系では吸着溶媒や鉄酸化物から構成され る皮膜が存在する。いずれの系でも下層に酸化鉄 $\mathrm{FeO}$ から構成される層が存在し，内部は金属 $\mathrm{Fe}$ のままであ る。

(Manuscript received December 5, 1996 ; in final form February 25, 1997)

\section{参 考 文 献}

1）久松敬弘 : 鉄と鋼, 63，574（1977）。

2) E. Heitz : Advance in Corrosion Science and Technology, Vol.4, Ed. by M. G. Fontana and R. W. Staehle, p.149, Plenum Press, New York (1974)

3 ) K. Schwade : Acid Corrosion of Metals in Nonaqueous Solvents, Verlag Technik, Berlin (1952).

4) A. Bukowiech : Metall, 13, 536 (1959).

5 ) W. Schmidt : Zashchita Metal (Met. Prot.), 5, 608 (1969)

6 ) J. J. Demo : Chem. Eng. World, 7, 115 (1972).

7) E. Heitz, M. Hukovic and K. H. Maier Werkst. u. Korr., 16, 178 (1965).

8 ) E. Heitz and T. Czepurnyi : ibid, 21, 1404 (1975).

9) R. G. Kerry and P. J. Moran : Corros. Sci., 30, 495 (1990).

10) C. A. Farina, G. Faita and F. Olivani : Corros. Sci., 18, 465 (1978).

11) I. Sekine and A. Chinda : Corrosion, 40, 95 (1984)

12) I. Sekine, S. Hatakeyama and Y. Nakazawa : Electrochimica Acta, 32, 500 (1987).

13) I. Sekine and K. Momoi : Corrosion, 44, 136 (1988)

14) I. Sekine and C. Okano : Corrosion, 45, 924 (1989) 
15）関根 功: 表面, 27, 160 (1989).

16) E. Heitz : Advance in Corrosion Science and Technology, Vol.4, Ed. by M. G. Fontana and R. W. Staeh le, p.163, Plenum Press, New York (1974).

17）大木道則, 大沢利昭, 田中元治, 千原秀昭編 : 「化学大辞典」, p.289, 東京化学同人 (1989).

18) L. M. Varsanyi, G. N. Markosyan, L. Sziraki, A. I. Molodov, A. Vertes, V. V. Losev and L. Kiss : Elektrokhimiya, 20, 625 (1984).

19）大木道則, 大沢利昭, 田中元治, 千原秀昭編 : 「化学大辞典」, p.771, 東京化学同人 (1989).

20）杉本克久，細谷敬三：防食技術，34，63（1985）.

21）高橋勝緒 : 電気化学, 53, 876 (1985).

22）島津 $\mathrm{X}$ 線光電子分析装置（ESCA）アプリケー ションデータ, No.1〜 53, 島津製作所.

23) K. Asami and K. Hashimoto : Corros. Sci., 17, 559 (1977).

24) W. W. Linstromberg, H. E. Baumgarten 共
著, 野副重男訳 : 「有機化学一その基礎の理解 —」, p.678, 東京化学同人 (1991).

25）J.マクマリー著，伊藤 敉，児玉三明，新井万 之助, 荻野敏夫, 恒次丈介, 通 元夫, 深沢義正 共訳 : 「有機化学」, p.203, 東京化学同人 (1987).

26) R. G. Kerry, P. J. Moran, C. Zollman, E. Gileadi and J. Kruger : J. Electrochem. Soc. 136, 3262 (1989).

27) C. Mann and K. Barnes : "Electrochemical Reaction in Nonaqueous Systems”, p. 452, Dekker, New York (1970).

28）腐食防食協会：「金属防食技術便覧」，p.642，日 刊工業新聞社（1977）。

29) U. R. Evans : Electrochim. Acta, 16, 1825 (1971).

30) T. P. Hoar, D. C. Mears and G. P. Rothwell : Corros. Sci., 5, 279 (1965).

31）荒巻国次：防食技術， 25，693（1976）. 